\title{
Evaluation of broiler partnership program with importance performance analysis in Kampar District, Riau Province
}

\author{
Deni Fitra*1) $^{* 1}$ Evi Irawati $^{1)}$, Hendro Tribowo ${ }^{1)}$, Gusti Robiwala ${ }^{1)}$ \\ 1) Animal Science, Faculty of Agriculture and Animal Science, UIN Sultan Syarif Kasim, \\ Riau, JL.HR.Soebrantas KM.15 Panam Pekanbaru. Indonesia, 28293
}

Submitted: 25 September 2019, Accepted: 18 May 2020

\begin{abstract}
This study aimed to evaluate the performance of broiler partnership program with importance performance analysis (IPA) approach and analyze its performance attributes that need to be improved and maintained in Kampar Regency, Riau Province. This descriptive study was done by using survey research methods on plasma farmers who has partnered with poultry companies, consisted of 30 plasma farmers in partnership with foreign capital companies, 10 plasma farmers in partnership with multinational companies and 6 plasma farmers in partnership with local companies. The samples were selected with purposive sampling method. The results of this study showed that the average service performance of the foreign capital partnership was 94.57 (very good), the multinational partnership was 95.22 (very good), while the local company partnership was 66.44 (good). Moreover, the local company partnership showed poor attributes on the feed quality and compensation. The service attributes that should be maintained by the foreign capital partnership were the suitability of harvest time, the response to all complaints, the suitability of output prices and the provision of compensation. Multinational partnership service attributes that should be maintained were the application of DOC contract prices, suitability of harvest time, response to all complaints, suitability of output prices, bonus price, and compensation. Moreover, the attributes of the services by the local company partnership that should be maintained were the drugs and vaccines qualities, technical guidance frequency as well as services and guidance material.
\end{abstract}

Keywords: Performance; Partnership; Importance Performance Analysis; Kampar

*Corresponding Author: deni.fitra@uin-suska.ac.id 


\section{INTRODUCTION}

One of the government's efforts in helping farmers was to encourage farmers to collaborate with other parties, or better known as partnerships. This was regulated in the Article 30 of Law No.18 of 2009 concerning animal husbandry and health. The main principle in partnership is equality, fairness and mutual benefit (Fitriza et al, 2012). Both parties that work together have an equal position based on their respective roles, so as to provide fair benefits for both parties. However, injustices are often found in the field. Most of the cooperation contracts that determine prices, bonuses, and production standards are determined and controlled unilaterally by the company.

There were several types of broiler partnership companies that operate in Riau Province, specifically Kampar Regency. Poultry companies with a foreign capital base include PT. Charoen Pokpand Indonesia, PT. Malindo and PT. Gold Coin. Aside from the foreign capital-based companies, there are also multinational companies such as PT. Japfa and PT. Sabas, and local partnership companies such as CV. Gunung Mas, Riau Feed Center and Prada Makmur Sejahtera. All of the plasma and independence broiler farmers in Kampar District reared around 17,313,332 broiler chicken in 2015 (BPS, 2016), the largest broiler population in Riau Province. Furthermore, the broiler population is dominated by broiler partnerships, both from foreign, national or local capital companies.

The assessment of partnership performance by companies against plasma farmers needs to be done, considering that in Kampar District there are many companies that open opportunities to partner with farmers. Therefore, efforts are needed to maintain the farmers' loyalty on the partnership program run by the company. One of the methods used to measure partnership performance is Importance Performance Analysis (IPA). The
Importance Performance Analysis (IPA) is an application analysis to evaluate the variables or attributes of importance and performance levels that are useful for developing more effective partnership program. The purposes of this study were 1). To understand the demographic of plasma farmers who are in the broiler partnerships in Kampar Regency, Riau Province. 2). To evaluate the broiler partnerships performances in Kampar District by using the Importance Performance Analysis (IPA), and 3). To analyse the performance attributes of broiler partnerships that need to be improved and that must be maintained for the future.

\section{MATERIALS AND METHODS Research Location and Time}

This research was conducted in the administrative area of Kampar Regency, Riau Province in September - December 2018.

\section{Materials}

This study evaluates 45 selected plasma farmers as research subjects, consisted of 30 plasma farmers from foreign capital enterprise partnership (KMA), 10 plasma farmers from multinational enterprise partnership (KMN), and 5 plasma farmers from local enterprise partnerships (KLK). The criteria for selected farmers were plasma farmers who have been on the partner program for at least 1 rearing period and have a minimum population of 5,000 broilers. The farmers were also divided into types of partnership companies, namely foreign, multinational and local enterprise.

\section{Methods}

This research is a descriptive study by using survey research methods on plasma farmers who are in partnership program with poultry companies. The selection of the location and farmers was done by using purposive sampling in Kampar Regency, Riau Province noting that the location has the largest broiler population and easily accessible. The primary data was collected by survey through interviews with 
questionnaire to the respondents. The obtained data were then compiled, analysed and described. The questions were related to the attributes of concern to plasma farmers, both on product and service attributes. The questionnaire was made based on five dimensions of service quality, namely reliability, responsiveness, assurance, empathy, and tangibility. The questionnaire attributes can be seen in Table 1 .

Table 1. List of Research Questionnaire Attributes

\begin{tabular}{|c|c|c|c|}
\hline Periods & No & Attributes & $\begin{array}{c}\text { Dimensions of Service } \\
\text { Quality }\end{array}$ \\
\hline & 1 & $\begin{array}{l}\text { Application of DOC contract } \\
\text { prices }\end{array}$ & Assurance \\
\hline & 2 & DOC quality & Tangibility \\
\hline Production & 3 & Price of a feed contract & Tangibility \\
\hline Facility & 4 & Feed quality & Tangibility \\
\hline \multirow[t]{3}{*}{ Services } & 5 & Prices of medicines and vaccines & Tangibility \\
\hline & 6 & Quality of medicines and vaccines & Tangibility \\
\hline & 7 & $\begin{array}{l}\text { Delivery schedule for production } \\
\text { facilities }\end{array}$ & Assurance \\
\hline \multirow{5}{*}{$\begin{array}{l}\text { Farming } \\
\text { Technical } \\
\text { Services }\end{array}$} & 8 & Frequency of technical guidance & Empathy \\
\hline & 9 & Services and guidance material & Assurance \\
\hline & 10 & $\begin{array}{l}\text { Application of production } \\
\text { standards }\end{array}$ & Assurance \\
\hline & 11 & Suitability of harvest time & Reliability \\
\hline & 12 & Response to all complaints & Responsiveness \\
\hline Post & 13 & Suitability of harvest prices & Assurance \\
\hline Harvest & 14 & Bonus & Reliability \\
\hline Services & 15 & Compensation & Reliability \\
\hline
\end{tabular}

\section{Observed Variables}

The variables observed in this study were demographic depictions of plasma farmers in Kampar Regency, Riau Province. Another observed variable was the performance of broiler partnerships in Kampar District by using the Importance Performance Analysis (IPA) approach. Importance and Performance Analysis (IPA) is an application technique to measure variables or attributes of importance and performance that is useful for developing effective marketing programs. This analysis uses the Likert scale 1-5. The Likert scale formula is as follows (Kusumah, 2008):

$$
\begin{aligned}
\mathrm{RS} & =\frac{\mathrm{ST}-\mathrm{SR}}{\mathrm{BS}}-0,01 \\
\mathrm{RS} & =\text { Scale Range } \\
\mathrm{ST} & =\text { Highest Scale } \\
\mathrm{SR} & =\text { Lowest Scale } \\
\mathrm{BS} & =\text { Many Scales }
\end{aligned}
$$

Table 2. Likert Scale Measurement of Importance and Performance

\begin{tabular}{lccll}
\hline \multicolumn{1}{c}{ Score } & Value & $\begin{array}{c}\text { Answer } \\
\text { Score }\end{array}$ & $\begin{array}{c}\text { Level of } \\
\text { Performance }(X)\end{array}$ & $\begin{array}{c}\text { Level of importance } \\
(Y)\end{array}$ \\
\hline $30,0-53,9$ & $1,00-1,79$ & 1 & Very dissatisfied & Very unimportant \\
$54,0-77,9$ & $1,80-2,59$ & 2 & Not satisfied & Not important \\
$78,0-101,9$ & $2,60-3,39$ & 3 & Neutral & Neutral \\
$102,0-125,9$ & $3,40-4,19$ & 4 & Satisfied & Important \\
$126,0-150$ & $4,20-5,00$ & 5 & Very satisfied & Very important \\
Source: Kusumah (2008) & & & &
\end{tabular}


The suitability assessment criteria for each attribute can be seen in the standards set by Kusumah (2008) below. Evaluation criteria for each attribute:

$$
\begin{array}{ll}
- & 0.81-1.00 \text { (Very Good) } \\
\text { - } & 0.66-0.80 \text { (Good) } \\
\text { - } & 0.51-0.65 \text { (Pretty Good) } \\
& 0.00-0.50 \text { (Bad) }
\end{array}
$$

Another observed variable was the performance attributes of broiler partnerships. The purpose of this analysis was to find out which attributes need to be improved and maintained for the future. The tool used for this analysis is the Cartesian diagram. The Cartesian diagram is a building of four sections bounded by two lines that intersect perpendicular to the points $(\overline{\mathrm{X}}, \overline{\mathrm{Y}})$ (Budianto, 2013).

\section{Data Analysis}

Data obtained from each observation variable were analysed by using Microsoft Excel to find the average value. While the Cartesian diagram analysis was done by using the SPSS 16 program. The results were further analysed by a descriptive analysis (Harsojuwono, et al 2011).

\begin{tabular}{c|c}
$\begin{array}{c}\text { Quadrant I } \\
\text { (Concentrate Here) }\end{array}$ & $\begin{array}{c}\text { Quadrant II } \\
\text { (Keep Up The Good Work) }\end{array}$ \\
$\begin{array}{c}\text { Attributes in this quadrant are } \\
\text { considered very important by } \\
\text { customers but the service is not } \\
\text { satisfactory so the company must } \\
\text { improve the quality of its services. }\end{array}$ & $\begin{array}{c}\text { Attributes in this quadrant are } \\
\text { considered very important by the } \\
\text { customer and the service is very } \\
\text { satisfying, so the company must } \\
\text { maintain the quality of its services. }\end{array}$ \\
\hline $\begin{array}{c}\text { Quadrant III } \\
\text { Low Priority) }\end{array}$ & $\begin{array}{c}\text { Quadrant IV } \\
\text { (Possible Overkill) }\end{array}$ \\
$\begin{array}{c}\text { Attributes in this quadrant are } \\
\text { considered unimportant by the } \\
\text { customer and the service is less than } \\
\text { satisfactory. }\end{array}$ & $\begin{array}{c}\text { Attributes in this quadrant are } \\
\text { considered not important by the } \\
\text { customer but the service is satisfying. }\end{array}$
\end{tabular}

Figure 1. Cartesian Diagram

\section{RESULTS AND DISCUSSION Demographic Characteristics of Plasma Farmers}

Based on survey, the age of plasma farmers was from 22 years to 62 years old. This means that not all of the respondents in this study were in the productive age, with around $6.67 \%$ of the respondents were more than 55 years old. Total respondents included in the productive age group amounted to $93.32 \%$ (age range 22-55 years old). Moreover, nearly 45 observed respondents were male with a percentage of $86.67 \%$, while the remaining $13.33 \%$ were women. This can be influenced by the tendency that men (husbands) play more of the breadwinner for the family. The women who raise broilers were only to assist their husbands in finding additional income for their family needs.

The total of farmers who had high school education were $84.44 \%$ of the total respondents, covering the most educational background by the respondents. This data showed that to be a broiler breeder, farmers did not require a high education, as it is practical, can be learned through training and workshops. However, the level of education will affect how the farmers think.

The status of a broiler business in the livelihood of the breeder illustrates the importance of the business, whether as a main business or a side business. From observations, there were several farmers 
who have other work outside of broiler farms, such as rice farmers, civil servants, BUMN employees and entrepreneurs. However, when the generated income from their work was smaller than the broiler rearing, the farmers decide that the broiler rearing was their main business, and amounted to $93.33 \%$ of total respondents.

Table 3. Demographic Characteristics

\begin{tabular}{|c|c|c|}
\hline \multirow{2}{*}{ Attributes } & \multicolumn{2}{|c|}{ Farmer Respondents } \\
\hline & Total & $\%$ \\
\hline \multicolumn{3}{|l|}{ Age (years) } \\
\hline $22-35$ & 28 & 62.22 \\
\hline $36-55$ & 14 & 31.11 \\
\hline$>55$ & 3 & 6.67 \\
\hline \multicolumn{3}{|l|}{ Sex } \\
\hline Man & 39 & 86.67 \\
\hline Woman & 6 & 13.33 \\
\hline \multicolumn{3}{|l|}{ Level of education } \\
\hline Elementary school & 1 & 2.22 \\
\hline Senior high school & 38 & 84.44 \\
\hline bachelor / diploma & 6 & 13.33 \\
\hline \multicolumn{3}{|l|}{ Business status } \\
\hline Side business & 3 & 6.67 \\
\hline Main Business & 42 & 93.33 \\
\hline
\end{tabular}

\section{Importance Performance Analysis (IPA)}

Importance Performance Analysis was done by calculating the total score of service performance and the consumers interest, in this case plasma farmers who partnered with broiler companies.

\section{Service Performance Score}

The IPA begins by determining the level of appropriateness between the level of importance and the level of performance of the examined attributes quality through comparison between performance scores with importance scores. The service quality performance of broiler companies to partner farmers in the Kampar Regency region was very good. Average score of KMA performance: 94.57 (Very Good), KMN: 95.22 (Very Good) and KLK: 66.44 (Good). Nevertheless, there were still some service attributes, especially in KLK that were unsatisfactory, including: feed quality with a service score of 41.38 (bad) and provision of compensation with a service score of 34.48 (bad). It was because KLK is a new local partnership which only operates in Kampar Regency, so it was assumed that its services were still un stable and optimal.

\section{Decision-making}

The value of the decision-making score will be compared with the level of suitability, if the value of the level of suitability is smaller than the value of the decision-making score (the average value of the level of suitability) then the attribute needs to be improved (Action) and if the level of conformity is greater than the decision-making score (average value of the level of conformity) then these attributes need to be maintained (Hold).

\section{Determination of Contract Prices and DOC Quality}

The DOC contract price applied to KMA was good, so it needs to be maintained (Hold). This was assumed because the supply of DOC to KMA directly from its subsidiaries such as from PT. CPJF (Charoen Pokphand Jaya Farm) where the relationship with KMA is still in one group of companies. Another assumption can be interpreted that the price of DOC given to farmers can be at a more affordable price. Whereas in the KMN and KLK the DOC contract pricing was still considered to be unfavourable because it was still in action 
(A) status. Higher contract prices than DOC prices on the market are assumed because DOC was not supplied by companies directly, but through many supply chain. DOC quality was still a problem for the three broiler partnership companies that collaborate with plasma farmers in the Kampar Regency. There was an assumption that the DOC given to plasma farmers was grade quality 2 and 3 .

Table 4. Score the suitability level of service quality performance attributes

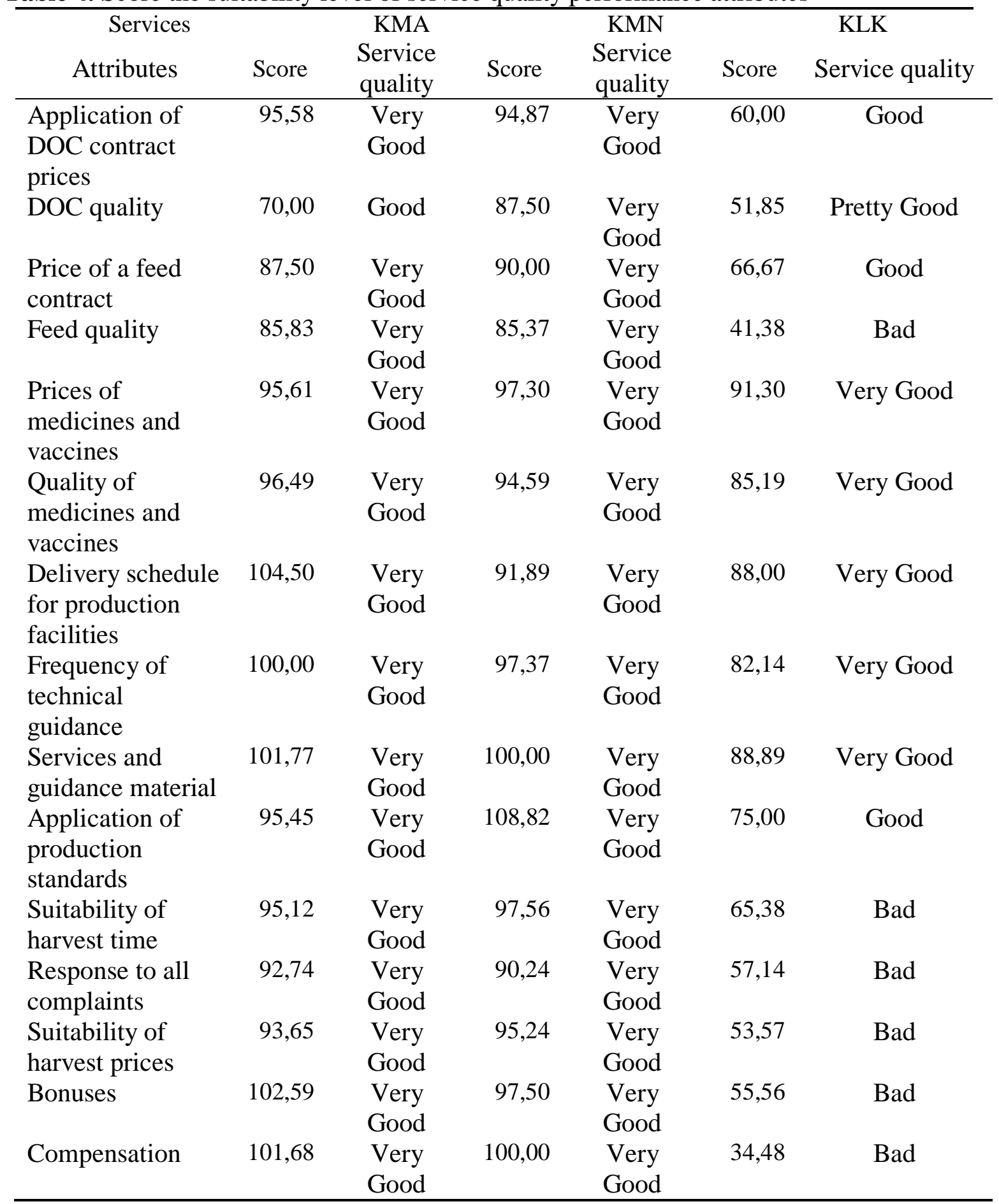


Table 5. Recapitulation of Decision Making

\begin{tabular}{lccc}
\hline \multirow{2}{*}{ Attributes } & \multicolumn{3}{c}{ Action / Hold } \\
\cline { 2 - 4 } & KMA & KMN & KLK \\
\hline Application of DOC contract prices & $\mathrm{H}$ & $\mathrm{A}$ & $\mathrm{A}$ \\
DOC quality & $\mathrm{A}$ & $\mathrm{A}$ & $\mathrm{A}$ \\
Price of a feed contract & $\mathrm{A}$ & $\mathrm{A}$ & $\mathrm{H}$ \\
Feed quality & $\mathrm{A}$ & $\mathrm{A}$ & $\mathrm{A}$ \\
Prices of medicines and vaccines & $\mathrm{H}$ & $\mathrm{H}$ & $\mathrm{H}$ \\
Quality of medicines and vaccines & $\mathrm{H}$ & $\mathrm{A}$ & $\mathrm{H}$ \\
Delivery schedule for production facilities & $\mathrm{H}$ & $\mathrm{A}$ & $\mathrm{H}$ \\
Frequency of technical guidance & $\mathrm{H}$ & $\mathrm{H}$ & $\mathrm{H}$ \\
Services and guidance material & $\mathrm{H}$ & $\mathrm{H}$ & $\mathrm{H}$ \\
Application of production standards & $\mathrm{H}$ & $\mathrm{H}$ & $\mathrm{H}$ \\
Suitability of harvest time & $\mathrm{H}$ & $\mathrm{H}$ & $\mathrm{A}$ \\
Response to all complaints & $\mathrm{A}$ & $\mathrm{A}$ & $\mathrm{A}$ \\
Suitability of harvest prices & $\mathrm{A}$ & $\mathrm{H}$ & $\mathrm{A}$ \\
Bonus & $\mathrm{H}$ & $\mathrm{H}$ & $\mathrm{A}$ \\
Compensation & $\mathrm{H}$ & $\mathrm{H}$ & $\mathrm{A}$ \\
\hline
\end{tabular}

Note: Calculated from questionnaire

\section{Determination of Contract Prices and DOC Quality}

The DOC contract price applied to KMA was good, so it needs to be maintained (Hold). This was assumed because the supply of DOC to KMA directly from its subsidiaries such as from PT. CPJF (Charoen Pokphand Jaya Farm) where the relationship with KMA is still in one group of companies.

Another assumption can be interpreted that the price of DOC given to farmers can be at a more affordable price. Whereas in the KMN and KLK the DOC contract pricing was still considered to be unfavourable because it was still in action (A) status. Higher contract prices than DOC prices on the market are assumed because DOC was not supplied by companies directly, but through many supply chain.

DOC quality was still a problem for the three broiler partnership companies that collaborate with plasma farmers in the Kampar Regency. There was an assumption that the DOC given to plasma farmers was grade quality 2 and 3 .

\section{Contract Prices and Feed Quality}

In contrast to DOC, the contract price and feed quality attributes for the observed partnership company were still problems that need to be sought for solutions. Farmers were still complaining about the contract price and feed quality provided by the partnership company, complaining about the high price of the feed contract, the slow growth of the chickens due to poor feed. KMA and KMN farmers felt the feed provided was higher in price and of poor quality. While for KLK farmers felt the high price of the feed contract, but the quality was better.

\section{Price and Quality of Medicines/Vaccines}

The price attributes and quality of medicines / vaccines were generally considered to be good because of their hold or can be maintained by each of the partnership companies in the Kampar Regency. However, specifically on the quality of medicines and vaccines in KLK, it was still complained by farmers and requires improvement quality of medicines.

\section{Delivery of Facilities and Infrastructure}

Only KMN farmers complained about the quality of this attribute, while others were already good and needed to be maintained. Complaints made by KMN farmers were usually around the delay of the DOC and feed delivery schedule from the agreed plan and the absence of schedule change communication. In addition, 
delivery of feed was often sudden, so farmers were sometimes not even ready to receive it.

\section{Frequency, Service and Technical Guidance Materials}

Animal farming technical guidance provided by the company to partner farmers is an important thing and is the key to the success of broiler partnership. Technical guidance was given by a PPL (Field Assistance Officer) who was appointed when the chickens were in. Guidance material provided in the form of feeding methods, medicines and vaccines until the chicken was ready to be harvested. In this service attribute, the three broiler partnership companies cooperating with farmers in Kampar Regency were already good and need to be maintained.

\section{Application of Production Standards}

The production standard is a limit that must be achieved by a farmer in farming broilers. The usual standards set by the company in the form of feed consumed, harvest weight, age of harvest and medicines. Although the production standards set by each partnership company are different, but data indicate that this attribute was Hold, it means that it was good and can be maintained.

\section{Suitability of Harvest Time and Price}

The harvest time suitability attribute for KMA and KMN can be maintained because it was considered good by plasma farmers, but for KLK it was still found differences in harvest time with the agreed contract. This can happen because of poor DOC quality, so that the harvest time was delayed.

While the suitability attribute of the harvest price, only in KMN where the farmers stated that they were in accordance with the harvest price with the agreed contract, while the KMA and KLK of the plasma farmer stated that it was not suitable and the harvest price needed to be improved. This was very important because it relates to the amount of income that will be obtained by partner farmers.

\section{Response to All Complaints}

In this observation, the partnership farmer still felts that all of his complaints had not been properly accommodated by the partnership company. All companies observed starting from KMA, KMN and KLK need to improve their services related to responses to farmers' complaints. The company's slow response when there were complaints from farmers was often conveyed.

\section{Bonus and Compensation}

The reliability dimension can be a source of motivation to be more productive and better. In the broiler partnership, bonuses and compensation such as performance index fees, elimination of harvest costs and security deposit deductions. Attributes of bonus and compensation in KMA and $\mathrm{KMN}$ were already felt appropriate and need to be maintained. While for KLK, farmers ask for improvements in terms of bonuses and compensation. This happens because it was assumed that KLK was a new and inexperienced company. To know the KMA and KMN who have decades of broiler business partnerships

\section{Cartesian diagram}

Cartesian diagrams have been used to see in detail the attributes that need to be improved and the attributes that must be maintained.

From the data in the table above, the partnership of foreign capital companies (KMA) must prioritize quality improvements, especially on improving the quality of DOC, updating feed contract prices and improving feed quality. While service attributes that were satisfactory and need to be maintained are suitability of harvest time, the response to all complaints, the suitability of harvest prices and compensation.

The main priority of the Multinational Company Partnership (KMN) was the same as the KMA, improving the quality of DOC, updating feed contract prices and improving feed quality. While service 
attributes that have been satisfying and need to be maintained are application of DOC contract prices, suitability of harvest time, response to all complaints, suitability of harvest prices, bonus giving and compensation.

Table 6. Cartesian diagram

\begin{tabular}{|c|c|c|c|c|}
\hline \multirow[b]{2}{*}{ Partnerships } & \multicolumn{4}{|c|}{ Cartesian diagram } \\
\hline & $\begin{array}{c}\text { Quadrant I } \\
\text { (Concentrate } \\
\text { Here) }\end{array}$ & $\begin{array}{l}\text { Quadrant II } \\
\text { (Keep Up The } \\
\text { Good Work) }\end{array}$ & $\begin{array}{l}\text { Quadrant III } \\
\text { (Low Priority) }\end{array}$ & $\begin{array}{l}\text { Quadrant IV } \\
\text { (Possible } \\
\text { Overkill) }\end{array}$ \\
\hline \multirow{4}{*}{$\begin{array}{l}\text { Foreign Capital } \\
\text { Partnership (KMA) }\end{array}$} & attribute 2 & attribute 11 & attribute 1 & attribute 7 \\
\hline & attribute 3 & attribute 12 & attribute 5 & attribute 8 \\
\hline & attribute 4 & attribute 13 & attribute 6 & attribute 9 \\
\hline & & attribute 15 & attribute 10 & attribute 14 \\
\hline \multirow{5}{*}{$\begin{array}{l}\text { The Multi -National } \\
\text { Partnership (KMN) }\end{array}$} & attribute 2 & attribute 1 & attribute 5 & attribute 8 \\
\hline & attribute 3 & attribute 11 & attribute 6 & attribute 9 \\
\hline & attribute 4 & attribute 12 & attribute 7 & attribute 10 \\
\hline & & attribute 13 & & \\
\hline & & $\begin{array}{l}\text { attribute } 14 \\
\text { attribute } 15\end{array}$ & & \\
\hline \multirow{5}{*}{$\begin{array}{l}\text { Local Company } \\
\text { Partnership (KLK) }\end{array}$} & attribute 2 & attribute 6 & attribute 1 & attribute 5 \\
\hline & attribute 4 & attribute 8 & attribute 3 & attribute 7 \\
\hline & attribute 12 & attribute 9 & attribute 11 & attribute 10 \\
\hline & attribute 13 & & & \\
\hline & $\begin{array}{l}\text { attribute } 14 \\
\text { attribute } 15\end{array}$ & & & \\
\hline
\end{tabular}

The local company partnership (KLK) must focus on prioritizing quality improvements, especially improving DOC quality, improving feed quality, improving response to complaints, updating harvest price adjustments, adjusting bonuses and compensation. While the service attributes that have been satisfying and need to be maintained are the quality medicines and vaccines, the frequency of technical guidance, services and guidance material.

\section{CONCLUSION}

Based on the results that have been stated above, conclude that:

1. Demographics of plasma farmers who are in partnership with broiler companies in Kampar Regency were dominated by farmers aged at 22-35 years old, male, with senior high school or equivalent educational background, and had their broiler farms as their main business.

2. Service quality from Importance performance analysis explains that the average service performance of the foreign capital partnership (KMA) was 94.57 (very good), the multinational partnership (KMN) was 95.22 (very good) and the local company partnership (KLK) was 66.44 (good).

3. Service attributes that need to be maintained from foreign capital partnerships (KMA) were the suitability of harvest time, the response to all complaints, the suitability of harvest 
prices and compensation. Service attributes that need to be maintained in a multi-national partnership (KMN) were the application of DOC contract prices, suitability of harvest time, response to all complaints, suitability of harvest prices, bonus giving and compensation. Whereas local company partnerships (KLK) need to maintain the quality attributes of medicines and vaccines, the frequency of technical guidance as well as service and guidance material.

\section{ACKNOWLEDGMENTS}

This work was financially supported in part of the Directorate of Islamic Higher Education Ministry of Religion of the Republic of Indonesia. We would like to thank for the individual cluster research grant in 2018.

\section{REFERENCES}

BPS. (2016). Kampar Dalam Angka. Riau: Badan Pusat Statistik.
Budianto, D. (2013). Analisis Kepuasan Konsumen terhadap Kualitas Pelayanan dan Harga Produk dengan menggunakan Metode Customer Satisfaction Index (CSI) dan Importance Performance Analysis (IPA) (Studi Kasus: Minimarket Garuda Pekanbaru). Universitas Islam Negeri Sultan Syarif Kasim.

Fitriza, Y. T., Haryadi, F. T., \& Syahlani, S. P. (2012). Analisis pendapatan dan persepsi peternak plasma terhadap kontrak perjanjian pola kemitraan ayam pedaging di Propinsi Lampung. Buletin Peternakan, 36(1), 57-65. https://doi.org/10.21059/buletinpetern ak.v36i1.1277

Harsojuwono, B. A., Arnata, I. W., \& Puspawati, G. A. K. D. (2011). Rancangan Percobaan. In Teori, Aplikasi SPSS dan Excel. Malang: Lintas Kata Publishing.

Kusumah, M. (2008). Analisis Tingkat Kepuasan Peternak Plasma terhadap Pola Kemitraan Tunas Mekar Farm di Kecamatan Nanggung, Kabupaten Bogor. Institut Pertanian Bogor. 